\title{
POTENSI EKSTRAK BUAH PARE (Momordica charantia L.) TERHADAP JUMLAH SEL LEYDIG DAN HORMON TESTOSTERON MENCIT (Mus musculus) JANTAN
}

\section{BITTER MELON (Momordica charantia L.) EXTRACT POTENCY TOWARD LEYDIG CELLS AMOUNT AND TESTOTERONE LEVEL OF THE MALE HOUSE MICE (Mus musculus)}

\author{
Faradillah Hapsari Dwi Putri ${ }^{1)}$, *Wurlina ${ }^{2)}$, Benjamin Christoffel Tehupuring ${ }^{3)}$ \\ ${ }^{1)}$ Student, ${ }^{2)}$ Veterinary Reproduction Department ${ }^{3)}$ Veterinary Anatomy Department \\ Faculty of Veterinary Medicine, Universitas Airlangga \\ *Corresponding author: wurlina_made@yahoo.co.id; faradillahhapsari@gmail.com
}

\begin{abstract}
The active compound in bitter melon, i.e., flavonoid, is allegedly inhibiting the formation of testoterone by Leydig cell. The aim of the research was investigating the Leydig cell and testoterone level due to the addition of bitter melon extract (Momordica charantia L.). This research was conducted on December 2016 at the Animal Testing Lab of Faculty of Veterinary Medicine Universitas Airlangga, while the production of histopathology preparations was at the pathology laboratory of Universitas Airlangga Surabaya, and the execution of testosterone level test was at Balai Besar Laboratorium Kesehatan Surabaya. The utilized research design was Completely Randomized Design, exploiting 20 male house mice which are divided into four experimental groups of 5 male house mice each. Each group had given the treatments of bitter melon extract of $23 \mathrm{mg} / \mathrm{kgBB}, 35 \mathrm{mg} / \mathrm{kgBB}, 45,5 \mathrm{mg} / \mathrm{kgBB}$, while the control group had given the drug solvent of CMC Na $1 \%$, which is conducted by utilizing feeding needles. In the $41^{\text {st }}$ day, the male house mice were being euthanized by cervical dislocation. The Leydig cells could be observed by utilizing 400x microscope zoom, while the testosterone was examined utilizing Enzym Linken Immunosorbent Assay (ELISA). The research result demonstrated that the bitter melon extract (Momordica charantia L.) addition could decrease the Leydig cells and the testosterone level.
\end{abstract}

Key words: bitter melon extract, Leydig cells, testosterone.

\section{Pendahuluan}

Indonesia merupakan negara berkembang yang mempunyai jumlah penduduk yang banyak. Menurut sensus penduduk Indonesia tahun 2005, penduduk Indonesia berjumlah 218,8 juta jiwa dengan laju pertambahan penduduk sekitar $1,3 \%$ per tahun (BPS, 2007).

Berkaitan dengan peningkatan jumlah penduduk, maka pemerintah Indonesia telah menjalankan Program Keluarga Berencana (KB) yang bertujuan untuk mensejahterakan rakyat melalui pembatasan kelahiran. Dalam program itu berbagai metoda kontrasepsi telah diperkenalkan, diantaranya memanfaatkan hormon dalam berbagai bentuk pil, AKDR (Alat Kontrasepsi Dalam Rahim), barrier, kontrasepsi jangka panjang, sterilisasi maupun metoda secara tradisional (Herman, 1996).
Pemanfaatan tumbuhan obat Indonesia untuk mengobati suatu penyakit biasanya hanya berdasarkan pengalaman empiris yang diwariskan secara turun temurun tanpa disertai data penunjang yang memenuhi persyaratan. Pemanfaatan dalam pengobatan modern,gv vc beberapa persyaratan yang harus dipenuhi terutama adalah khasiat, tingkat keamanannya disamping kandungan zat aktifnya yang dapat diprediksi dengan mudah (Atamini, 2001).

Salah satu tanaman obat yang digunakan oleh masyarakat dalam mengatasi masalah kesehatan adalah dengan memanfaatkan buah pare (Momordica charantia L.) (Hernawati, 2006). Buah pare mengandung zat aktif yang meliputi lemak kasar, protein kasar, serat makanan, mineral, minyak esensial, flavonoid, asam fenolat, glycolsides, dan triterpenoid. Zat aktif 
triterpenoid dan flavonoid yang terkandung dalam buah pare tersebut dapat berperan sebagai antifertilitas baik bagi hewan jantan maupun hewan betina (Ifeanyi et al., 2011).

Berdasarkan latar belakang yang telah dipaparkan, perlu dilakukan penelitian tentang pengaruh pemberian ekstrak buah pare (Momordica charantia L.) terhadap jumlah sel Leydig mencit (Mus musculus) jantan, beberapa bahan aktif yang terkandung dalam buah pare yang diduga berpotensi sebagai bahan yang bersifat antifertilitas pada mencit jantan.

\section{Materi dan Metode Penelitian}

Sebanyak 20 ekor mencit (Mus musculus) jantan dibagi secara acak menjadi 4 kelompok, sehingga tiap kelompok terdiri dari 5 ekor. Mencit (Mus musculus) jantan diadaptasikan dalam kondisi dan pakan yang sama selama 7 hari sebelum perlakuan di kandang hewan coba Fakultas Kedokteran Hewan Universitas Airlangga. Ekstrak buah pare (Momordica charantia L.) diberikan selama 40 hari.

Sesuai dengan penelitian yang dilakukan Siti Cholifah (2014) pemberian ekstrak buah pare (Momordica charantia L.) selama 56 hari secara per oral diperoleh dosis perlakuan sebagai berikut

Kontrol (P0) = pelarut obat CMC Na $1 \%$

Perlakuan $1(\mathrm{P} 1)=$ Ekstrak buah pare (Momordica charantia L.) dosis 23 $\mathrm{mg} / \mathrm{kgBB}$

Perlakuan $2(\mathrm{P} 2)=$ Ekstrak buah pare (Momordica charantia L.) dosis 35 $\mathrm{mg} / \mathrm{kgBB}$

Perlakuan $3(\mathrm{P} 3)=$ Ekstrak buah pare (Momordica charantia L.) dosis 45,5 $\mathrm{mg} / \mathrm{kgBB}$

\section{Analisis Data}

Data yang diperoleh dianalisis dengan Analysis of Variance (ANOVA) pada tingkat signifikasi 5\%, apabila terdapat perbedaan yang bermakna maka dilanjutkan dengan uji jarak berganda Duncan
(Kusriningrum, 2011) dengan menggunakan fasilitas Statistical Programe for Social Science (SPSS) for Windows 20.00 tingkat signifikansi 5\%.

\section{Hasil dan Pembahasan}

Tabel 4.1 Rerata dari data jumlah sel Leydig pada gambaran histopatologi testis mencit (Mus musculus) setiap perlakuan

\section{Sel Leydig}

Dari hasil pengamatan terlihat bahwa perlakuan dengan berbagai variasi dosis ekstrak buah pare (Momoridica charantia L.) menunjukkan adanya kecenderungan penurunan jumlah rata-rata sel Leydig. Penurunan jumlah rata-rata sel Leydig kemungkinan disebabkan oleh senyawasenyawa kimia dari tanaman buah pare (Momordica charantia L.) yang bersifat menghambat proliferasi sel.

Penurunan jumlah sel Leydig ini disebabkan karena flavonoid dan kukurbitasin yang berikatan dengan reseptor estrogen mengakibatkan sekresi FSH menurun dan LH terhambat. Karena sekresi LH terhambat maka menyebabkan pertumbuhan dan jumlah sel Leydig berkurang sehingga sekresi hormon testosteron juga ikut berkurang (Winarno dkk, 2002).

\section{Hormon Testosteron}

Senyawa flavonoid yang terkandung dalam buah pare akan memberikan umpan balik negatif terhadap poros hipotalamus hipofisis testis sehingga akan menurunkan sekresi Luteinizing hormone (LH) maupun Follicle Stimulating Hormone (FSH). Penurunan LH dapat menekan pembentukan testosteron secara langsung pada sel Leydig, sehingga terjadi gangguan keseimbangan hormonal (Hernawati, 2006).

Testosteron merupakan hormon yang esensial dalam spermatogenesis, selain itu hormon testosteron juga berfungsi untuk

Tabel 1. Rerata dari data jumlah sel Leydig pada testis mencit (Mus musculus) setiap perlakuan

\begin{tabular}{cc}
\hline Perlakuan & Jumlah sel Leydig (mean \pm SD) \\
\hline P0 & $5.08^{\mathrm{b}} \pm 1.06$ \\
P1 & $4.58^{\mathrm{b}} \pm 0.16$ \\
P2 & $3.56^{\mathrm{a}} \pm 0.29$ \\
P3 & $2.80^{\mathrm{a}} \pm 0.35$ \\
\hline
\end{tabular}


Tabel 2. Rerata dari data hormon testosteron pada testis mencit (Mus musculus) setiap perlakuan

\begin{tabular}{cc}
\hline Perlakuan & Hormon Testosteron $($ mean \pm SD) \\
\hline 0 & $0.21^{\mathrm{b}} \pm 0.18$ \\
P1 & $0.19^{\mathrm{b}} \pm 0.11$ \\
P2 & $0.15^{\mathrm{a}} \pm 0.16$ \\
P3 & $0.13^{\mathrm{a}} \pm 0.03$ \\
\hline
\end{tabular}

mempertahankan kelenjar asesoris namun dalam kadar yang tinggi didalam tubuh justru mempunyai sifat umpan balik negatif. Dengan adanya peningkatan kadar hormon tersebut maka timbul efek umpan balik negatif terhadap hipotalamus dan hipofisis anterior. Jika terjadi efek umpan balik negatif pada hipotalamus maka sekresi GnRH (Gonadotrophin Releasing Hormone) akan terhenti sehingga menghambat sekresi gonadotropin (LH dan FSH) oleh hipofisis anterior. Luteinizing hormone (LH) berfungsi merangsang sel Leydig untuk menghasilkan testosteron, sedang Follicle Stimulating Hormone (FSH) berfungsi merangsang spermatogenesis dan pembentukan protein pengikat androgen ABP (Androgen Binding Protein) oleh sel Sertoli (McLachlan, 2000).

\section{Jumlah Sel Leydig dan Kadar Hormon Testosteron}

Penurunan jumlah sel Leydig testis mencit yang dicapai dalam penelitian ini terbukti dipengaruhi oleh besarnya dosis pemberian ekstrak buah pare. Dalam hal ini zat aktif tersebut mampu mempengaruhi kerja hormon. Banyaknya kandungan bahan aktif yang terkandung dalam buah pare diantaranya flavonoid dan triterpenoid mampu mengurangi produksi hormon testosteron (Ilyas, 2004).

Dosis ekstrak buah pare terbaik terdapat pada $\mathrm{P} 2$ yaitu 35 mg.kgBB yang mampu menurunkan jumlah sel Leydig dan kadar hormon testosteron. Berdasarkan penelitian ini maka, pemberian ekstrak buah pare (Momordica charantia L.) selama 40 hari dapat mengurangi jumlah sel Leydig dan kadar hormon testosteron secara nyata.

\section{Kesimpulan}

Berdasarkan hasil penelitian dan pembahasan sebelumnya, maka dapat disimpulkan bahwa pemberian ekstrak buah pare
(Momordica charantia L.) dengan dosis 23 $\mathrm{mg} / \mathrm{kgBB}, \quad 35 \mathrm{mg} / \mathrm{kgBB}, \quad 45,5 \mathrm{mg} / \mathrm{kgBB}$ selama 40 hari dapat menurunkan jumlah sel Leydig dan kadar hormon testosteron mencit (Mus musculus) jantan.

\section{Daftar Pustaka}

Atamini F. 2001. Tiga senyawa baru cassanefu-rano diterpen hasil isolasi dari daging biji Bogore (Caesalpinia erista L.) asal Sulawesi Selatan sebagai bahan dasar obat antimalaria. Sci. \& Tech. 1: 12-24.

Cholifah, Siti., Arsyad dan Salni. 2014. Pengaruh Pemberian Ekstrak Pare (Momordica charantia L.) Terhadap Struktur Histologi Testis dan Epididimis Tikus Jantan (Rattus norvegicus) Spraque Dawley. 149-157.

Herman, M.J. 1996. Pemanfaatan Hormon Dalam Kontrasepsi. Cermin Dunia Kedokteran. 112: 5-11.

Hernawati. 2006. Potensi Buah Pare (Momordica charantia L.) sebagai Herbal Antifertilitas. Fakultas Pendidikan Matematika dan Ilmu Pengetahuan Alam Universitas Pendidikan Indonesia. Bandung.

Ifeanyi, A.C., Y.O. Eboetse., D.F. Ikechukwu., O.A. Adewale., N.C. Carmel and O.A. Olugbenga. 2011. Effect of Momordica charantia on Estrous cycle of Sparague-Dawley rats. Pacific Journal of Medical Sciences. 8(1): 37-48.

Ilyas, S. 2004. Ilmu Penyakit Mata Edisi Ketiga. Balai Penerbit FKUI. Jakarta.

McLachlan, RI. 2000. Male hormonal contra-ception: A safe acceptable and reversible choice. Long-activity testosterone/progestin combinations show great promise as contaceptives. The medical Journal of Australia. 172. 245-255. 
Winarno, M.W, B. Nuratmi dan Y. Astuti.

2002. Pengaruh Infus Buah Pare

(Momordica charantia L) terhadap

Kelenjar Prostat Tikus Putih. Media

Litbang Kesehatan. XII(2): 41-45. 